\title{
Guidelines in Supporting People with Intellectual Disabilities.It's all About Values
}

\author{
Jos H M van Loon ${ }^{1 *}$, Remco Mostert ${ }^{2}$ \\ ${ }^{1}$ Department of Special Education of the Ghent University \& Ghent University College, Belgium \\ ${ }^{2} B S W$, University College Ghent, School of Social Welfare
}

Submission: September 04, 2020; Published: October 05, 2020

*Corresponding author: Jos H M van Loon, Department of Special Education of the Ghent University \& Ghent University College, Belgium

\begin{abstract}
In a person-centered support system for people with intellectual disabilities, there should be an alignment between the wishes and goals of a person, his or her support needs, the support given, and his or her quality of life as outcome. Thus far, quite some research has been done on measuring support needs and measuring personal outcomes. In this article the focus is on the actual support to people with intellectual disabilities. It is argued that there should be an emphasis on 1) the application of evidence-based supports, 2) based on evidence-based measurement of support needs, 3) in which the outcomes are evidence-based assessed quality of life-related personal outcomes, 4) within a value-based framework, and 5) in a process of methodological sound Individual Supports Planning. A value-based model for evidence-based supports and interventions in a support methodology is presented.
\end{abstract}

Keywords: Intellectual disability; Evidence-based practices; Methodology

\section{Introduction}

For organizations providing supports to persons with intellectual disability, it is their main task to enhance the quality of life (QOL) of their clients. In a person-centered support system, there should be an alignment between the wishes and goals of a person, his or her support needs, the support given, and his or her quality of life as outcome. It is important to adjust the methodology of how to support people in the direction of a complete personcentered support methodology (input-throughput-output) [1-3].

Thus far, quite some research has been done on measuring support needs and measuring outcomes. For example, the support needs of a person can, in a reliable and valid way, be measured by the Supports Intensity Scale [4]. The outcomes of an individual supports plan for a person should be an enhanced quality of life. Evidence-based outcomes (EBOs) are a critical component of evidence-based practices [5]. Determining whether these outcomes occur, requires the reliable and valid assessment of quality of life-related domains. The Personal Outcomes Scale (POS; [1], which is based on the QOL conceptual model and measurement framework by Schalock \& Verdugo [6], was developed for that purpose.

In this article we focus on the actual support to people with intellectual disabilities. The present contribution will in this respect focus on 1) the application of evidence-based supports, 2) based on evidence-based measurement of support needs, 3) in which the outcomes are evidence-based assessed quality of liferelated personal outcomes, 4) within a value-based framework and 5) in a process of methodological sound Individual Supports Planning.

If there is an alignment between wishes and goals, assessed support needs, individual supports, and quality of life outcomes, there is an excellent opportunity to enhance clinical decisions regarding how to support people methodically in improving their quality of life.

\section{A Framework}

Enhancing Quality of Life, supporting people, working with methods and interventions needs a vision, a framework. It is here important to explicitly express the framework within which the concrete support to people takes place. The vision from where we work, the values that we adhere to, the pedagogical climate, the attitude, conditions, environmental factors: these are all factors within which the concrete support is provided, within which methods are used.

In our view, the UN Convention on the Rights of People with Disabilities (CRPD) and the quality of life-related domains set the 
values, within which the delivery of support should take place. In the CRPD themes such as human dignity, participation / inclusion and accessibility of society, equality and equal opportunities, autonomy and self-determination, empowerment and physical, emotional and material well-being are important. Quality of life is defined as a multidimensional phenomenon composed of core domains that constitute personal well-being. These domains are influenced by personal characteristics and environmental factors. One's quality of life is the product of and can be enhanced through quality enhancement strategies that encompass developing personal talents, maximizing personal involvement, providing individualized supports, and facilitating personal growth opportunities. QOL domains are the set of factors composing personal well-being. The set represents the range over which the QOL concept extends and thus defines the multi-dimensionality of a life of quality. The eight core QOL domains, described in the QOL - model by Schalock \& Verdugo [7,8] are extensively researched and validated in a number of cross-cultural studies; these domains are: emotional well-being, interpersonal relations, material well-being, personal development, physical well-being, self-determination, social inclusion, and rights. Verdugo, Navas, Gomez \& Schalock [9] found a close relationship between the QOL domains as developed by Schalock \& Verdugo [10] and the UN Convention Articles; these articles can be evaluated assessing indicators associated with the eight QOL domains.

Furthermore, one of the current challenges for these organizations, which is more and more emphasized, is the need to use evidence-based practices. Evidence-based practices (EBPs) are defined as practices that are based on current best evidence that is obtained from credible sources that used reliable and valid methods and a clearly articulated and empirically supported theory or rationale [11].

This means that the supports given by a service provider should be value-based and evidence-based, and lead to good evidence-based outcomes: good quality of life related personal outcomes.

\section{What are effective factors?}

In determining whether supports are evidence-based, there is also the question of the effectiveness of interventions discussed. In youth care van Yperen \& Boendermaker [12] conducted a literature study on effective factors. They cite studies of Lambert and colleagues about the effectiveness of psychotherapeutic interventions, which states that the method represents only $15 \%$ of the result. Otherwise, the results would be mainly determined by factors that are beyond the specific methodology.

Lambert and his colleagues found that forty percent is attributable to extra-therapeutic factors (client factors such as a child who is intelligent being treated for behavioral problems, and therefore easily picks up instructions from the worker, and environmental factors. According to them thirty percent can be explained by generally effective factors ("common factors" such as the quality of the relationship between the caregiver and the client and the extent to which the proceeds help structured).

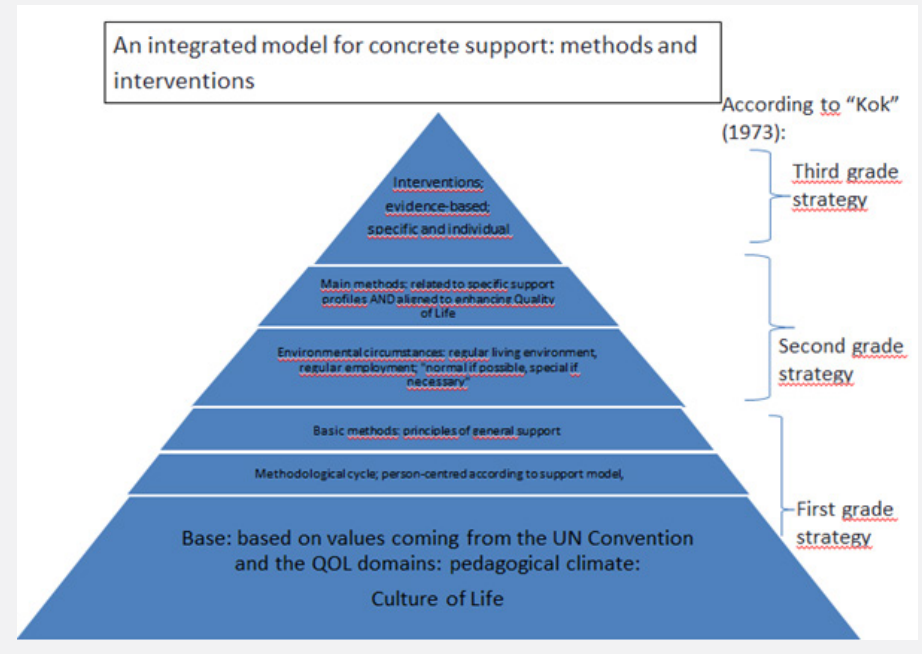

Figure 1: An Integrated model for concrete support: methods and interventions.

Other studies come up with different figures, but the overall trend is that the contribution of the various specific forms of therapy is at best mediocre. More general factors seem to have a stronger influence. Well-known examples of these factors are:

a) Fit the motivation of the client;

b) Good quality of the relationship client-therapist; c) Proper structuring of the intervention (clear objective, planning and phasing);

d) A good 'fit' of the approach to the problem and the demand for assistance;

e) Implementation of the intervention as it should be performed; 


\section{Global Journal of Intellectual \& Developmental Disabilities}

f) professionalism (good education and training) of the practitioner;

g) good working conditions of the treatment (as bearable caseload, good support, rescue safety).

h) These factors seem comparatively generally have a strong effect.

Jongepier Struijk \& Van der Helm [13] emphasize, according to Kok (who speaks of the importance of a good first line strategy) the importance of an open living climate. They mention the seven main characteristics:

(i) Contacting clients (1. 'Responsibility')

(ii) Ensure that clients understand the need for their residential treatment and can learn from their treatment $(2$. "Growth")

(iii) Ensure a good atmosphere (3. 'Structure, security and positive interactions')

(iv) All this has to be organized with as little coercion and punishment, without many and often incomprehensible rules, with the highest degree of clarity, structure and self-determination (4. 'No repression')

(v) An open climate is characterized by an adequate conflict management style by support workers aimed at solving problems rather than conflict and dominance (5. Adequate conflict management in social problems)

(vi) Clients are respected at all times (6. "Do not reject the client but his behavior")

(vii) In an open environment for children and adults with a mild intellectual disability, there is also day-structuring (7. Day Structure) because these clients have difficulty constructing their own structure (learning how to structure themselves in the day can also be an important treatment goal).

\section{Methodical considerations}

Then there are also methodical considerations that are important in developing a framework for interventions. Here one can think of following the methodical cycle, person-centeredness, and following the program-logic model. Lombardi \& Schalock [14] conducted a study on factors that predict the quality of life of people with intellectual disabilities. They argue on the basis of their research, among 1285 people with ID in 23 organizations, that the emphasis should be on providing support that is tailored to the specific domain of quality of life, and on the basis of the support needs of the individual person. The support process should be person centered and based on personal needs and goals.

\section{Environmental factors}

It is obvious that environmental circumstances are important in enhancing Quality of Life. Schalock [15] in this regard speaks of the importance of focusing on creating environments instead of focusing on services, as main task of an organization. A study by Claes, Van Hove, Vandevelde, van Loon \& Schalock [16] in an organization for people with ID shows that environmental factors (living independently, a regular job or having volunteer job) were related to a higher QOL. Also Lombardi, Croce, Claes Vandevelde \& Schalock [14] found that it is clear that people who live in smaller residential settings and participate in community activities, such as a regular job and / or a volunteer job, have a better quality of life.

\section{Alignment with QOL}

Schalock [15] gives an overview of the various components of a system of supports. In 2014 Schalock aligned Quality of Life Domains to Potential Support Strategies and Anticipated Effects. We combined these tables to come to an overview which can be of help in deciding which support strategies potentially can be used in developing individual support plans. In Table 2 we give an example for two domains. Of course, the support strategies mentioned in Table 2 are exemplary. It will be necessary to elaborate on these [17].

Table 1: Guidelines for developing interventions in support.

Guidelines for Developing Interventions in Support

1. The a) values, based on the UN Convention on the Rights of People with Disabilities and the QOL domains, and b) evidence based general factors regarding the efficacy of interventions set the framework, within which interventions and methods should take place.

2. In this framework there is also a place for methodological and substantive conditions for which interventions and methods to use.

3. Recent theoretical perspectives on human functioning as the model of the ICF (WHO, 2001) or the AAIDD [7] highlight the importance of a socio-ecological approach: a functional and multidimensional conceptualization of disability, in which not the "defect" but the functioning of people is central.

4. There should be good environmental conditions: a good environment to live in.

5. There should be an alignment to QOL and a system of supports

6. Specific evidence-based interventions (aligned to the QOL domains and the system of supports) should comply with the criterion to be called evidence-based: a firm relation should be demonstrated between the specific interventions and measured outcomes. 
Table 2: Interventions aligned tot the QOL domains.

\begin{tabular}{|c|c|c|c|}
\hline \multicolumn{4}{|c|}{ Interventions Aligned to the QOL Domains } \\
\hline QOL domain & $\begin{array}{l}\text { Related compo- } \\
\text { nents of a system of } \\
\text { supports }\end{array}$ & Exemplary support strategies & Anticipated effects \\
\hline \multirow{3}{*}{$\begin{array}{l}\text { Social Inclu- } \\
\text { sion }\end{array}$} & Natural Supports & Access/interface with natural supports & $\begin{array}{l}\text {-Increased community access, participation, and } \\
\text { involvement }\end{array}$ \\
\hline & $\begin{array}{l}\text { Reasonable accommo- } \\
\text { dation }\end{array}$ & $\begin{array}{l}\text { Ensuring physical accessibility of buildings, } \\
\text { transport, and workspaces; creating secure and } \\
\text { predictable environments; and providing physical } \\
\text { and other accommodations that allow individuals } \\
\text { to negotiate their environment and carry out } \\
\text { daily tasks }\end{array}$ & $\begin{array}{l}\text { Enhanced personal development, community living, } \\
\text { integrated employment } \\
\text { Increased social inclusion, interpersonal relations, } \\
\text { social-emotional well-being }\end{array}$ \\
\hline & Professional services & $\begin{array}{c}\text { Use of social media } \\
\text { Facilitate transportation } \\
\text { Use prosthetics (sensory or motor devices) } \\
\text { Active support }\end{array}$ & $\begin{array}{l}\text { Make sure that people who need support have the } \\
\text { chance to be fully involved in their lives and receive } \\
\text { the right range and level of support to be successful }\end{array}$ \\
\hline \multirow[b]{3}{*}{$\begin{array}{l}\text { Emotional } \\
\text { Well-Being }\end{array}$} & Natural Supports & $\begin{array}{l}\text { Building and maintaining support networks } \\
\text { Provide safe and predictable environments }\end{array}$ & $\begin{array}{l}\text {-Reduce fear and anxiety } \\
\text {-Increase motivation and satisfaction }\end{array}$ \\
\hline & Professional services & $\begin{array}{c}\text { Access professional services } \\
\text { Maximize incentives (e.g. rewards, opportunities } \\
\text { to be successful) }\end{array}$ & $\begin{array}{l}\text {-Reduce challenging behaviors and increase positive } \\
\text { interactions } \\
\text {-Maximize mental/ behavioral health }\end{array}$ \\
\hline & Dignity and respect & $\begin{array}{l}\text { Use positive behavioral supports } \\
\text { Gentle Teaching Enhancing social role status } \\
\text { through community involvement, equal opportu- } \\
\text { nity, recognition, appreciation, financial security, } \\
\text { honors, personal goal setting, empowerment, and } \\
\text { control of an individual supports plan. }\end{array}$ & $\begin{array}{c}\text {-Increased motivation and achievement } \\
\text {-Safety, security, engagement, being unconditionally } \\
\text { valued }\end{array}$ \\
\hline
\end{tabular}

\section{A model for evidence-based supports and interventions in a support methodology}

If we take the above considerations together, the following model for evidence-based supports and interventions in a support methodology can be sketched.

(i) The values, based on the UN Convention and the QOL domains, and evidence based general factors regarding the efficacy of interventions set the framework, within which interventions and methods should take place. In this framework there are also methodological and substantive conditions for which interventions and methods to use.

(ii) Then there are environmental conditions (iii) There should be an alignment to QOL and a system of supports

(iv) Then there are specific evidence-based interventions (aligned to the QOL domains and the system of supports) which should comply with the criterion to be called evidence-based: a firm relation should be demonstrated between the specific interventions and measured outcomes.

\section{Conclusion}

The alignment between 1) wishes and goals of the person, 2) evidence-based measurement of support needs, 3) the application of evidence-based supports, 4) in which the outcomes are evidence-based assessed quality of life-related personal outcomes, 4) within a value-based framework, and 5) in a 
process of methodological sound Individual Supports Planning, creates an excellent opportunity to support people methodically in improving their quality of life. In this article we emphasize the importance of values in supporting people. Values, based on the UN Convention on the Rights of People with Disabilities and the QOL domains, and evidence based general factors regarding the efficacy of interventions together should set the framework, within which interventions and methods should take place.

\section{References}

1. van Loon J, Van Hove G, Schalock RL, Claes C (2008) Personal Outcomes Scale: A Scale to Assess an Individual's Quality of Life. Stichting Arduin Netherlands: Universiteit Gent. Belgium.

2. Van Loon J (2015) Planes Individuales De Apoyo: Mejora De Los Resultados Personales. Siglo Cero 46 (1): 25-40.

3. Van Loon J, van Wijk P (2016) Organizational Transformation. In Schalock, R.L. \& Keith, K.D. (edn.) (2016) Cross-Cultural Quality of Life: Enhancing the lives of people with intellectual disability. Second Edition. Washington: American Association on Intellectual and Developmental Disabilities. pp: 284.

4. Thompson J T, Bryant B R, Campbell E M, Craig E M, Hughes C M, Rotholz D A, et al. (2004) Support Intensity Scale Manual. Washington, DC: American Association on Mental Retardation. USA.

5. Claes C, Van Hove G, Vandevelde S, van Loon J, Schalock R L (2011) The Influence of Supports Strategies, Environmental Factors, and Client Characteristics on Quality of Life-Related Personal Outcomes. Research in Developmental Disabilities 33(1): 96-103.

6. van Loon J, Claes C, Van Hove G, Schalock R L (2010) De ontwikkeling van de Persoonsgerichte Ondersteuningsuitkomsten Schaal (POS). Nederlands Tijdschrift voor de Zorg aan mensen met verstandelijke beperkingen 36(3): 180-196.

7. Schalock R L (2014) Aligning Quality of Life Domains to Potential Support Strategies and Anticipated Effects. Handout at a meeting in $\mathrm{Ar}$ duin.

8. Verdugo M A, Navas P, Gómez L E, Schalock R L (2012) The concept of quality of life and its role in enhancing human rights in the field of intellectual disability. Journal of Intellectual Disability Research 56(11): 1036-1045.

9. Schalock R L, Verdugo M A (2002) Handbook on quality of life for human service practitioners. Washington, DC: American Association on Mental Retardation. USA.

10. Schalock R L, Verdugo M A, Gomez E (2011) Evidence-based practices in the field of Intellectual and developmental disabilities: An international consensus approach. Evaluation and Program Planning 34(3): 273-282.

11. Van Yperen T, van der Steege M, Addink A, Boendermaker L (2010) Algemene en specifiek werkzame factoren in de jeugdzorg. Stand van de discussie. Nederlands jeugdinstituut, Utrecht.

12. Jongepier N, Struijk M, Van der Helm G H P (2010) Zes uitgangspunten voor een goed pedagogisch klimaat [Six factors that contribute to a living climate]. Jeugd en co 9 (1).

13. Marco Lombardi M, Croce L, Claes C, Vandevelde S, Schalock R L (2016) Factors predicting quality of life for people with intellectual disability: Results from the ANFFAS study in Italy, Journal of Intellectual \& Developmental Disability 41(4): 338-347.

14. van Loon, Jos H M, Swart K (2017) A Knowledge Library. Based on a model for evidence-based support strategies and interventions in a support methodology.

15. Van Loon Jos (2008) Een Persoonsgerichte Ondersteuningsmethodiek Het methodisch bevorderen van kwaliteit van bestaan voor mensen met een verstandelijke beperking. In Van Loon, Jos \& Van Hove, Geert (Red.) (2008) Arduin. Persoonsgerichte Ondersteuning en Kwaliteit van Bestaan. Leuven-Apeldoorn: Garant

16. van Loon J, Jos H M, Van Hove G, Schalock R L (2009) The use of SIS data / items for the development of an individual supports plan. In: Schalock R L, Thompson J. The SIS Implementation Guide. Washington, DC: American Association on Intellectual and Developmental Disabilities. USA.

17. van Loon, Jos H M, Bonham Gordon S, Peterson, Dale D, et al. (2013) The Use of Evidence-Based Outcomes in Systems and Organizations Providing Services and Supports to Persons with Intellectual Disability. Evaluation and Program Planning, 36(1): 80-87.

\section{Your next submission with Juniper Publishers will reach you the below assets}

- Quality Editorial service

- Swift Peer Review

- Reprints availability

- E-prints Service

- Manuscript Podcast for convenient understanding

- Global attainment for your research

- Manuscript accessibility in different formats

( Pdf, E-pub, Full Text, Audio)

- Unceasing customer service

Track the below URL for one-step submission https://juniperpublishers.com/online-submission.php 